\title{
THE FEMININE PUBLIC SPHERE
}

MIDDLE-CLASS WOMEN AND CIVIC

LIFE IN SCOTLAND, C. 1870-1914

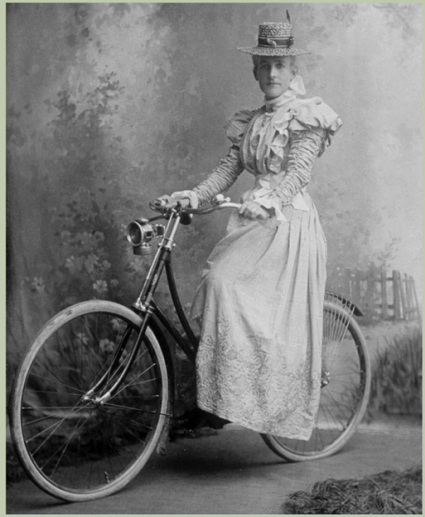

Megan Smitley - 9781847793461

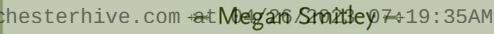
via free access 


\title{
GENDER IN HISTORY
}

\author{
Series editors: \\ Lynn Abrams, Cordelia Beattie, Pam Sharpe and Penny Summerfield
}

\begin{abstract}
$\Longleftarrow$
The expansion of research into the history of women and gender since the 1970 s has changed the face of history. Using the insights of feminist theory and of historians of women, gender historians have explored the configuration in the past of gender identities and relations between the sexes. They have also investigated the history of sexuality and family relations, and analysed ideas and ideals of masculinity and femininity. Yet gender history has not abandoned the original, inspirational project of women's history: to recover and reveal the lived experience of women in the past and the present.

The series Gender in History provides a forum for these developments. Its historical coverage extends from the medieval to the modern period, and its geographical scope encompasses not only Europe and North America but all corners of the globe. The series aims to investigate the social and cultural constructions of gender in historical sources, as well as the gendering of historical discourse itself. It embraces both detailed case studies of specific regions or periods, and broader treatments of major themes. Gender in History titles are designed to meet the needs of both scholars and students working in this dynamic area of historical research.
\end{abstract}

\section{The feminine public sphere}

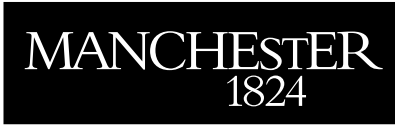

Manchester University Press 


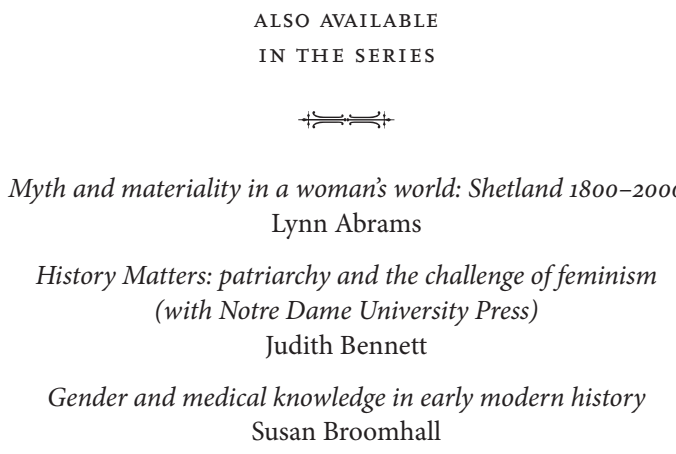

'The truest form of patriotism': pacifist feminism in Britain, 1870-1902 Heloise Brown

Artisans of the body in early modern Italy: identities, families and masculinities Sandra Cavallo

Women of the right spirit: Paid organisers of the Women's Social and Political Union (WSPU) 1904-18

Krista Cowman

Masculinities in politics and war: gendering modern history Stefan Dudink, Karen Hagemann and John Tosh (eds)

Victorians and the Virgin Mary: religion and gender in England 1830-1885 Carold Engelhardt Herringer

Living in sin: cohabiting as husband and wife in nineteenth-century England Ginger S. Frost

Murder and morality in Victorian Britain: the story of Madeleine Smith Eleanor Gordon and Gwyneth Nair

The military leadership of Matilda of Canossa, 1046-1115 David J. Hay

The shadow of marriage: singleness in England, 1914--60 Katherine Holden

Women police: Gender, welfare and surveillance in the twentieth century Louise Jackson

Noblewomen, aristocracy and power in the twelfth-century Anglo-Norman realm Susan Johns

The business of everyday life: gender, practice and social politics in England, c.1600-1900 Beverly Lemire

The independent man: citizenship and gender politics in Georgian England Matthew McCormack 


\section{THE FEMININE \\ PUBLIC SPHERE \\ MIDDLE-CLASS WOMEN IN \\ CIVIC LIFE IN SCOTLAND, \\ C. $1870-1914$}

$\asymp$ Megan Smitley

Manchester University Press

Manchester and New York

distributed exclusively in the USA by Palgrave 


\section{Copyright (C) Megan Smitley 2009}

The right of Megan Smitley to be identified as the author of this work has been asserted by her in accordance with the Copyright, Designs and Patents Act 1988.

Published by Manchester University Press

Oxford Road, Manchester M13 9NR, UK

and Room 400, 175 Fifth Avenue, New York, NY 10010, USA

www.manchesteruniversitypress.co.uk

Distributed exclusively in the USA by Palgrave

175 Fifth Avenue, New York,

NY 10010, USA

Distributed exclusively in Canada by UBC Press

University of British Columbia, 2029 West Mall,

Vancouver, BC, Canada v6T 1Z2

British Library Cataloguing-in-Publication Data

A catalogue record for this book is available from the British Library

Library of Congress Cataloging-in-Publication Data applied for

ISBN 978 o 719079665 hardback

First published 2009

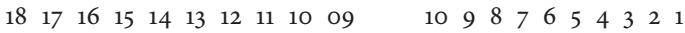

Typeset in Minion with Scala Sans display

by Koinonia, Manchester

Printed in Great Britain

by MPG Books Group 